Check for updates

Cite this: RSC Adv., 2018, 8, 40490

Received 8th September 2018

Accepted 28th November 2018

DOI: $10.1039 / c 8 r a 07502 f$

rsc.li/rsc-advances

\title{
A facile synthesis of molybdenum carbide nanoparticles-modified carbonized cotton textile as an anode material for high-performance microbial fuel cells $\dagger$
}

\begin{abstract}
Lizhen Zeng, ${ }^{\text {ac }}$ Shaofei Zhao, ${ }^{b}$ Lixia Zhang ${ }^{d}$ and Miao He (D) *a
A novel macroscale porous structure electrode, molybdenum carbide nanoparticles-modified carbonized cotton textile $\left(\mathrm{MO}_{2} \mathrm{C} / \mathrm{CCT}\right)$, was synthesized by a facile two-step method and used as an anode material for high-performance microbial fuel cells (MFCs). The characterization results show that the carbonized cotton textile modified with $\mathrm{MO}_{2} \mathrm{C}$ nanoparticles offers a great specific surface area $\left(832.17 \mathrm{~m}^{2} \mathrm{~g}^{-1}\right)$ for bacterial adhesion. The MFC using $\mathrm{Mo}_{2} \mathrm{C} / \mathrm{CCT}$ anode delivers the maximum power density of $1.12 \mathrm{~W} \mathrm{~m}^{-2}$, which is $51 \%$ and $116 \%$ higher than that of CCT and unmodified carbon felt anodes under the same conditions. The high power density is mainly due to the $\mathrm{MO}_{2} \mathrm{C}$ nanoparticles with good biocompatibility and high conductivity and superior electrochemical activity, as well as the macroscale porous structure of carbonized cotton textile, which facilitate the formation of electroactive biofilm and improve the electron transfer. This paper introduces a feasible way to synthesize cost-effective and highperformance anode materials for MFCs.
\end{abstract}

\section{Introduction}

As a representative bio-electrochemical system, microbial fuel cells (MFCs) can use microorganisms to decompose waste, achieving waste treatment and producing electricity with mild operating conditions and environmentally friendly characteristics, which has provided a new direction to solve energy and environmental issues and become a hot research topic in recent years. ${ }^{1-3}$ However, the large-scale commercial applications of MFCs have been mainly inhibited by the low power density and high cost of MFCs., ${ }^{4,5}$

Unlike hydrogen fuel cells and other chemical fuel cells, due to the role of microorganisms, the anode is regarded as a crucial factor affecting the performance of MFCs, which exerts a great impact on bacterial adhesion, electron transfer and substrate oxidation. ${ }^{6,7}$ Therefore, a suitable anode material is beneficial to improve the performance of MFCs. Accordingly, an ideal anode

${ }^{a}$ School of Physics and Optoelectronic Engineering, Guangdong University of Technology, Guangzhou 510006, China. E-mail: herofategdut@126.com

${ }^{b}$ School of Chemical Engineering and Light Industry, Guangdong University of Technology, Guangzhou 510006, China

'Analysis and Testing Center, South China Normal University, Guangzhou 510006, China

${ }^{d}$ CAS Key Laboratory of Environmental and Applied Microbiology, Environmental Microbiology Key Laboratory of Sichuan Province, Chengdu Institute of Biology, Chinese Academy of Sciences, Chengdu 610041, China

$\dagger$ Electronic supplementary information (ESI) available. See DOI: 10.1039/c8ra07502f material requires good biocompatibility, excellent conductivity, excellent stability, large specific surface area, high porosity and low-cost. ${ }^{7,8}$ Nowadays, carbon-based materials and graphitebased materials are the most used commercial anode materials in MFCs, while their relatively smooth surfaces are not conducive to the bacterial adhesion. ${ }^{9}$ If insufficient bacterial cells adhere on the anode, the transfer efficiency of electrons from the microbial metabolism to the anode via extracellular electron transport (EET) is hindered and hence limits the performance of MFCs. ${ }^{3,10}$ Thus, the low performance of anode material is the major obstacle to limiting the power density of MFCs. ${ }^{11}$

In our previous report, CCT and NC@CCT have been developed as low-cost and high-performance anode materials of MFCs. ${ }^{8}$ Yet, CCT and NC@CCT exhibits poor electrocatalytic activity. Noble metal nanomaterials have been explored as anode materials to improve the catalytic performance of MFCs. ${ }^{3}$ In order to improve the electrochemical activity of CCT for facilitating the catalytic oxidation of substrate, modifying with noble metal (such as Pt) nanomaterials could be a good idea. ${ }^{3} \mathrm{Pt}$ nanoparticles are excellent electrocatalyst material, have superior performance, such as good catalytic activity and high electron transfer efficiency, which are very suitable for applicable in catalysts and other fields. ${ }^{3,12}$ However, the high cost of Pt-based materials has limited their application. ${ }^{13}$ As we all know, molybdenum carbide $\left(\mathrm{Mo}_{2} \mathrm{C}\right)$ is one of classic transition metal carbides, which not only has Pt-like electronic and catalytic properties, but also low-cost. ${ }^{\mathbf{1 4 - 1 7}} \mathrm{Mo}_{2} \mathrm{C}$ nanomaterials 
possess high electrical conductivity and unique catalytic activity for many chemical processes, such as fast redox reactions with protons on the surface. ${ }^{18}$ More importantly, $\mathrm{Mo}_{2} \mathrm{C}$ nanoparticles exhibit good biocompatibility and excellent electrocatalytic activity towards oxidation of bacterial metabolites. ${ }^{19-22}$ Unfortunately, as previously reported, the conditions for synthesis of $\mathrm{Mo}_{2} \mathrm{C}$ nanoparticles are very strict and the true of product is hard to control. ${ }^{20,21}$

In this study, $\mathrm{Mo}_{2} \mathrm{C} / \mathrm{CCT}$ was developed as anode material for high-performance MFCs via a facile two-step method (dipping and carbonization treatment). The $\mathrm{Mo}_{2} \mathrm{C} / \mathrm{CCT}$ electrode provides a high conductivity, a rough surface and a large specific surface area for bacterial adhesion on the anode, facilitates the formation of electroactive biofilm, as well as displays superior electrochemical activity. The MFC using $\mathrm{Mo}_{2} \mathrm{C} / \mathrm{CCT}$ anode has better performance than which using CCT and unmodified carbon felt anodes under the same conditions. This paper demonstrates a feasible method to prepare costeffective and high-performance anode material for MFCs.

\section{Materials and methods}

\subsection{Preparation of $\mathrm{Mo}_{2} \mathrm{C} / \mathrm{CCT}$}

$\mathrm{Mo}_{2} \mathrm{C} / \mathrm{CCT}$ was prepared via a facile two-step method (dipping and carbonization method). Typically, waste cotton textiles were prepared according to our previous report. ${ }^{8}$ As-prepared cotton textile was dipped into $2 \mathrm{~mol} \mathrm{~L}^{-1}$ ammonium heptamolybdate tetrahydrate $\left(\left(\mathrm{NH}_{4}\right)_{6} \mathrm{Mo}_{7} \mathrm{O}_{24} \cdot 4 \mathrm{H}_{2} \mathrm{O}\right.$, Aladdin $)$ aqueous solution under stirring for $24 \mathrm{~h}$, then dried at $60{ }^{\circ} \mathrm{C}$ for $24 \mathrm{~h}$. Finally, the dried ammonium molybdate modified cotton textile (AM/CCT) was carbonized at $1000{ }^{\circ} \mathrm{C}$ for $1 \mathrm{~h}$ under inert gas (Ar) condition. The blank CCT was used for comparison. In addition, using the same method, cotton textiles dipped in different concentrations of $\left(\mathrm{NH}_{4}\right)_{6} \mathrm{Mo}_{7} \mathrm{O}_{24} \cdot 4 \mathrm{H}_{2} \mathrm{O}$ aqueous solution ( $1 \mathrm{~mol} \mathrm{~L}^{-1}$ and $3 \mathrm{~mol} \mathrm{~L}^{-1}$ ) and carbonized, which were denoted as $\mathrm{Mo}_{2} \mathrm{C} / \mathrm{CCT}-1$ and $\mathrm{Mo}_{2} \mathrm{C} / \mathrm{CCT}-3$, respectively.

\subsection{Materials characterization}

The XRD patterns of $\mathrm{Mo}_{2} \mathrm{C} / \mathrm{CCT}$ and CCT were recorded on Bruker D8 Advance X-ray diffractometer (Germany) with $\mathrm{Cu} \mathrm{K} \alpha$ radiation $(\lambda=1.5405 \mathrm{~nm})$. The Raman spectroscopy was recorded with a confocal microscope Raman spectrometer system (Lab RAM Aramis, HORIBA, France). The surface morphologies of samples and biofilms were characterized with field emission-scanning electron microscopy (FE-SEM, ZESISS Gemini 500, Germany). The samples and biofilms were coated with platinum (Pt) with a coating device (Quorum Q150TES, UK) before observation. The energy dispersive X-ray microanalysis system (EDS) analysis and the quantitative element mapping analysis were carried out on Oxford instrument IET250 spectrometer (Oxford, UK). The X-ray photoelectron spectroscopy (XPS) measurements were measured using ESCALAB 250 (Thermo Fisher Scientific, USA) with an $\mathrm{Al} \mathrm{K \alpha}$ (mono) irradiation $(1486.6 \mathrm{eV})$. The electrical resistivity measurement was carried out on a four-probe conductivity measurement device (RST-8, Guangzhou). The specific surface area of $\mathrm{Mo}_{2} \mathrm{C} / \mathrm{CCT}$ and
CCT samples were measured using an accelerated surface area and porosimetry system (Micrometrics, ASAP 2020, USA) and calculated according to Brunauer-Emmett-Teller (BET) method.

\subsection{MFC construction, operation and tests}

Universal air-cathode cylindrical MFCs were constructed as Logan et al. previously reported. ${ }^{23}$ The $\mathrm{Mo}_{2} \mathrm{C} / \mathrm{CCT}$ anode $(2.0 \mathrm{~cm}$ $\times 2.0 \mathrm{~cm} \times 0.1 \mathrm{~cm})$ and cathode were connected to an external resistor $(1000 \Omega)$ via titanium wire. CCT and unmodified carbon felt (CF) electrodes with the same size were also used as anodes for comparison. The cathode was a carbon paper coated with $\mathrm{Pt} /$ $\mathrm{C}$ catalyst ( $0.5 \mathrm{mg} \mathrm{cm}^{-2}$ Pt loading) and prepared as described in previous report. ${ }^{24}$

The MFC reactors were inoculated with $5.0 \mathrm{~mL}$ mixed bacterial suspension from the effluent of matured singlechamber MFC which had been originally inoculated with activated anaerobic sludge. ${ }^{24}$ The reactors were fed with sodium acetate-growth medium including sodium acetate $\left(1 \mathrm{~g} \mathrm{~L}^{-1}\right)$ as the electron donor and culture medium solution consisting of $50 \mathrm{mmol}$ phosphate buffer solution $(\mathrm{pH} 7.0), 12.5 \mathrm{~mL} \mathrm{~L}^{-1}$ vitamin solution and $12.5 \mathrm{~mL} \mathrm{~L}^{-1}$ mineral solution. When the MFCs approached steady state, the polarization and power density curves were obtained by changing the external resistance from 8000 to $100 \Omega$. The power density $\left(P, \mathrm{~W} \mathrm{~m}^{-2}\right)$ was calculated as follows: $P=U^{2} / R$, where $U(\mathrm{~V})$ and $R(\Omega)$ are the output voltage and the external resistance, respectively. The $P$ was normalized by the projected area of anode surface $\left(4.0 \mathrm{~cm}^{2}\right)$. The MFCs were operated in batch-fed mode at $30{ }^{\circ} \mathrm{C}$. All the measurements were performed with three MFCs for each sample.

Electrochemical measurements were performed on an electrochemical station (Autolab PGSTAT-302N, Metrohm Co., Switzerland) with a traditional three-electrode system: the anode, the saturated calomel electrode (SCE) and the titanium wire were used as the working electrode, reference electrode and counter electrode, respectively. The chronopotentiometry (CP) was measured after the MFC forming a stable biofilm with the applied current of $0.1 \mu \mathrm{A}$. The electrochemical impedance spectroscopy (EIS) was conducted at open circuit potential versus SCE in a frequency range from 10000 to $0.01 \mathrm{~Hz}$ with an amplitude of $5 \mathrm{mV}$.

\section{Results and discussion}

\subsection{Characteristics of $\mathrm{Mo}_{2} \mathrm{C} / \mathrm{CCT}$}

The $\mathrm{Mo}_{2} \mathrm{C} / \mathrm{CCT}$ was synthesized by a facile two-step method. Fig. 1 illustrates the synthesis procedure of $\mathrm{Mo}_{2} \mathrm{C} / \mathrm{CCT}$. The techniques of XRD and Raman spectroscopy were utilized to determine the composition of the prepared sample. Fig. 2a presents the XRD patterns of $\mathrm{Mo}_{2} \mathrm{C} / \mathrm{CCT}$ and CCT. As shown in Fig. 1a, the $\mathrm{Mo}_{2} \mathrm{C} / \mathrm{CCT}$ has several main diffraction peaks at $26.7^{\circ}, 37.9^{\circ}, 61.1^{\circ}, 67.5^{\circ}$ and $79.7^{\circ}$, which was corresponding with $\mathrm{Mo}_{2} \mathrm{C}$ (JCPDS, no. 35-787). The diffraction peak was at $26.7^{\circ}$, which can be assigned as the (002) reflection of graphite, corresponding to a graphitic carbon. No other peak could be 




Fig. 1 Schematic illustrating the synthesis route of $\mathrm{MO}_{2} \mathrm{C} / \mathrm{CCT}$.

detected. Comparing with the X-ray diffraction pattern of CCT, it can be concluded that the $\mathrm{Mo}_{2} \mathrm{C} / \mathrm{CCT}$ mainly contains $\mathrm{Mo}_{2} \mathrm{C}$. Fig. $2 \mathrm{~b}$ presents the Raman spectrum of the $\mathrm{Mo}_{2} \mathrm{C} / \mathrm{CCT}$ and CCT, there are two characteristic peaks around 1350 and $1600 \mathrm{~cm}^{-1}$ corresponding to the $\mathrm{D}$ and $\mathrm{G}$ bands of graphitic carbon. Notably, the Raman spectrum of $\mathrm{Mo}_{2} \mathrm{C} / \mathrm{CCT}$ contains a weak peak around $970 \mathrm{~cm}^{-1}$, which can be attributed to the characteristic band of molybdenum carbide..$^{25-27}$ The results of XRD and Raman spectroscopy demonstrate that the prepared sample has been successfully modified with $\mathrm{Mo}_{2} \mathrm{C}$ nanoparticles.

The energy dispersive X-ray microanalysis system (EDS) analysis was further used to confirm the composition of $\mathrm{Mo}_{2} \mathrm{C} /$ CCT and CCT. As Fig. 2c depicted, the $\mathrm{Mo}_{2} \mathrm{C} / \mathrm{CCT}$ is mainly composed of C, O, Mo and trace Si elements. Pt originates from the EDS measurement. While as, only $\mathrm{C}, \mathrm{O}$ and trace $\mathrm{Si}$ elements can be detected in CCT. Consequently, the $\mathrm{Mo}_{2} \mathrm{C} / \mathrm{CCT}$ sample contains $\mathrm{Mo}_{2} \mathrm{C}$. It is worth noting that all elements don't have effect on the growth of bacteria in the MFC experiments. Fig. 2d shows the nitrogen adsorption-desorption isotherm curves of $\mathrm{Mo}_{2} \mathrm{C} / \mathrm{CCT}$ and CCT, both of which represent typical IV characteristics, and the corresponding specific surface area of $\mathrm{Mo}_{2} \mathrm{C} /$ CCT composite is about $832.17 \mathrm{~m}^{2} \mathrm{~g}^{-1}$, which is about four times higher than that of CCT $\left(209.64 \mathrm{~m}^{2} \mathrm{~g}^{-1}\right)$. Therefore, it illustrates that the $\mathrm{Mo}_{2} \mathrm{C} / \mathrm{CCT}$ provides a larger specific surface area and more potential active sites for bacterial adhesion and growth. ${ }^{28}$
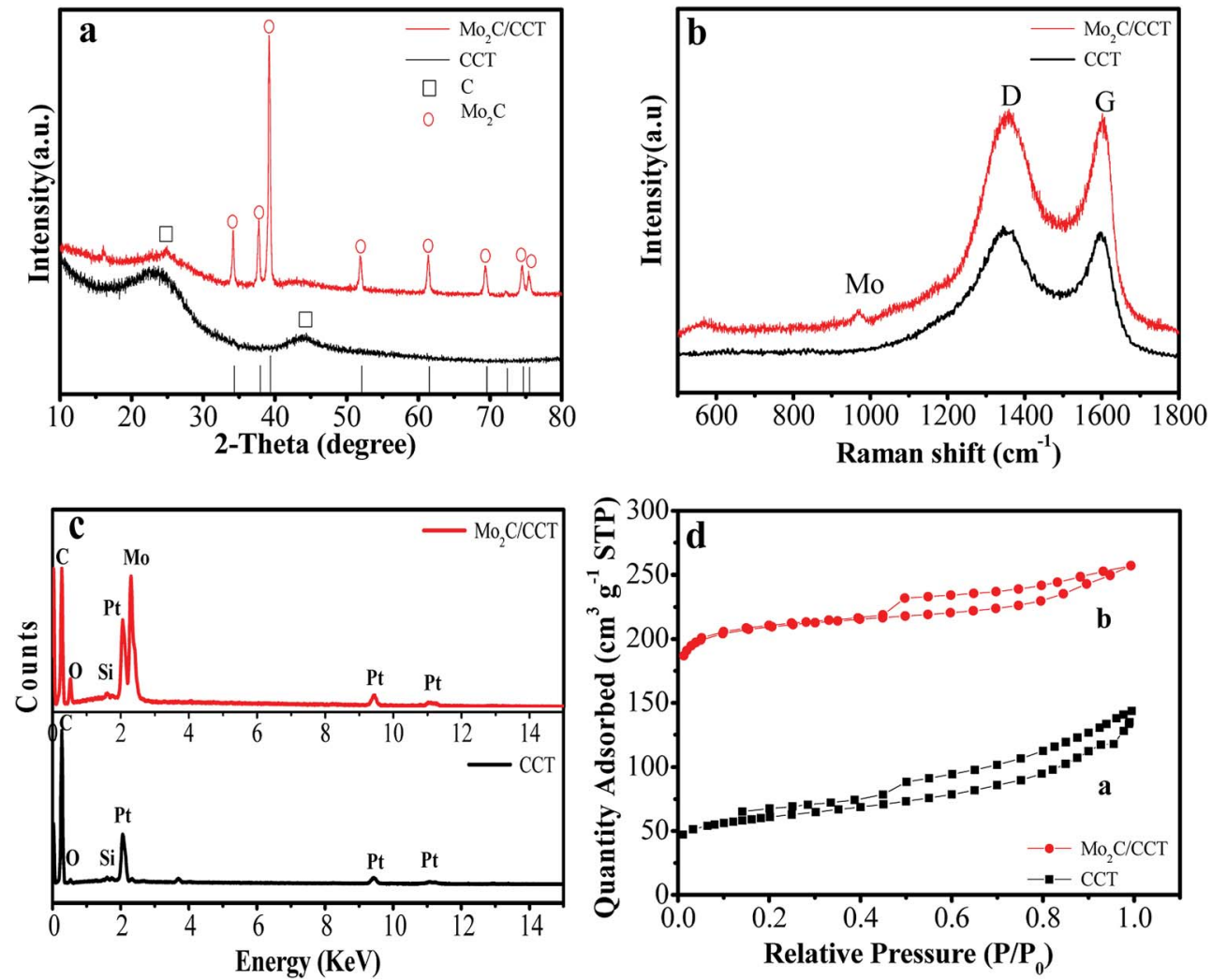

Fig. 2 X-ray diffraction patterns (a); Raman spectra (b); energy-dispersive X-ray spectra (c); nitrogen adsorption-desorption isotherms (d) of $\mathrm{MO}_{2} \mathrm{C} / \mathrm{CCT}$ and $\mathrm{CCT}$ samples. 

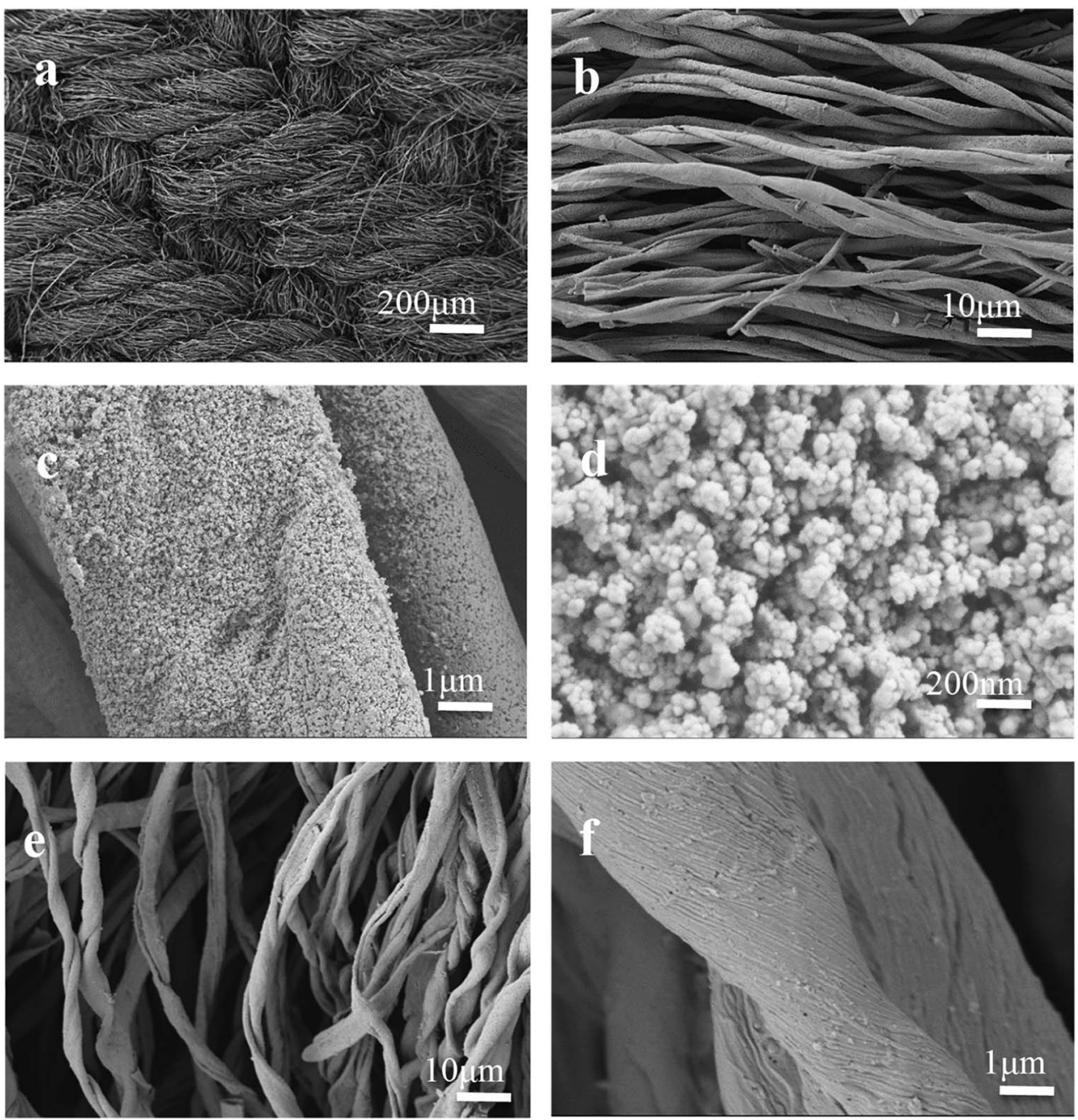

Fig. 3 SEM images of $\mathrm{Mo}_{2} \mathrm{C} / \mathrm{CCT}(\mathrm{a}-\mathrm{d})$ and $\mathrm{CCT}$ (e and f) at various magnifications.

The morphology of $\mathrm{Mo}_{2} \mathrm{C} / \mathrm{CCT}$ was characterized by FESEM. Fig. 3 shows the SEM images of $\mathrm{Mo}_{2} \mathrm{C} / \mathrm{CCT}$ and CCT at various magnifications. It can be observed easily from Fig. 3a and $\mathrm{b}$ that, the $\mathrm{Mo}_{2} \mathrm{C} / \mathrm{CCT}$ is composed of fibers. The macroscale porous structure of the intertwined carbonized cotton textile fibers (Fig. 3b) produces an open space (approximately $10 \mu \mathrm{m}$ ). As Fig. 3c depicted, the fiber is coated by many nanoparticles after simple dipping of ammonium molybdate and carbonization treatment. Obviously, it is seen from the high-resolution SEM image of $\mathrm{Mo}_{2} \mathrm{C} / \mathrm{CCT}$ (Fig. 3d) that many nanoparticles are modified on the fiber surface and the surface of $\mathrm{Mo}_{2} \mathrm{C} / \mathrm{CCT}$ is highly rough. Notably, the surface of CCT was relatively smooth (Fig. 3e and f). The good conductivity and rough surface of $\mathrm{Mo}_{2} \mathrm{C}$ nanoparticles could result in stronger electrostatic interaction and faster electron transfer rate between bacteria and anode, thus largely increases the loading amount of bacteria. ${ }^{22}$

To reveal the surface compositions and electronic state of $\mathrm{Mo}_{2} \mathrm{C} / \mathrm{CCT}$, X-ray photoelectron spectroscopy (XPS) measurement was carried out. As depicted in the survey XPS spectrum (Fig. 4a), five characteristic signals locate at 233.6, 285.8, 398.1, $416.5,532.2 \mathrm{eV}$, corresponding to Mo 3d, C 1s, N 1s, Mo 3p and
$\mathrm{O}$ 1s, respectively. ${ }^{29}$ From the $\mathrm{C} 1 \mathrm{~s}$ spectra of $\mathrm{Mo}_{2} \mathrm{C} / \mathrm{CCT}$ (Fig. 4b), the characteristic peaks at 284.4, 284.8 and $285.5 \mathrm{eV}$ can be attributed to $\mathrm{C}-\mathrm{Mo}, \mathrm{C}=\mathrm{C}$ and $\mathrm{C}-\mathrm{C}$, respectively. ${ }^{29,30}$ The Mo 3d spectra of $\mathrm{Mo}_{2} \mathrm{C} / \mathrm{CCT}$ (Fig. 4c) shows the diffraction peaks at 232.0, 232.8, 234.5, 235.6, $236.2 \mathrm{eV}$, which can be attributed to $\mathrm{Mo} 3 \mathrm{~d}$ of $\mathrm{Mo}_{2} \mathrm{C}$ and oxidized molybdenum with intermediate oxidation states $\left(\mathrm{MoO}_{x}\right)$. The $\mathrm{MoO}_{x}$ may be generated by the oxidization of $\mathrm{Mo}_{2} \mathrm{C}$ during the XPS measurement. From the $\mathrm{N} 1 \mathrm{~s}$ spectra (Fig. 4d), the characteristic peaks at 397.6, 398.4, 399.8 and $401.7 \mathrm{eV}$, which are assigned to pyridinic, pyrrolic, graphitic and oxidized nitrogen, respectively. ${ }^{31}$ The nitrogen group might be coated on the $\mathrm{Mo}_{2} \mathrm{C} / \mathrm{CCT}$ sample due to pyrolysis of ammonium molybdate. As Tang et al. reported, nitrogen-doped on the anode will enhance biocatalytic activity and thus favors bacterial adhesion and facilitates electron transfer between anode and bacteria. ${ }^{32}$ Besides, carbon-based anodes have been treated with ammonia to strengthen the interaction between the anode and the bacteria. ${ }^{33}$

In order to further determine the element composition and distribution of $\mathrm{Mo}_{2} \mathrm{C} / \mathrm{CCT}$, the corresponding EDS quantitative element mapping analysis was performed. The SEM image of 

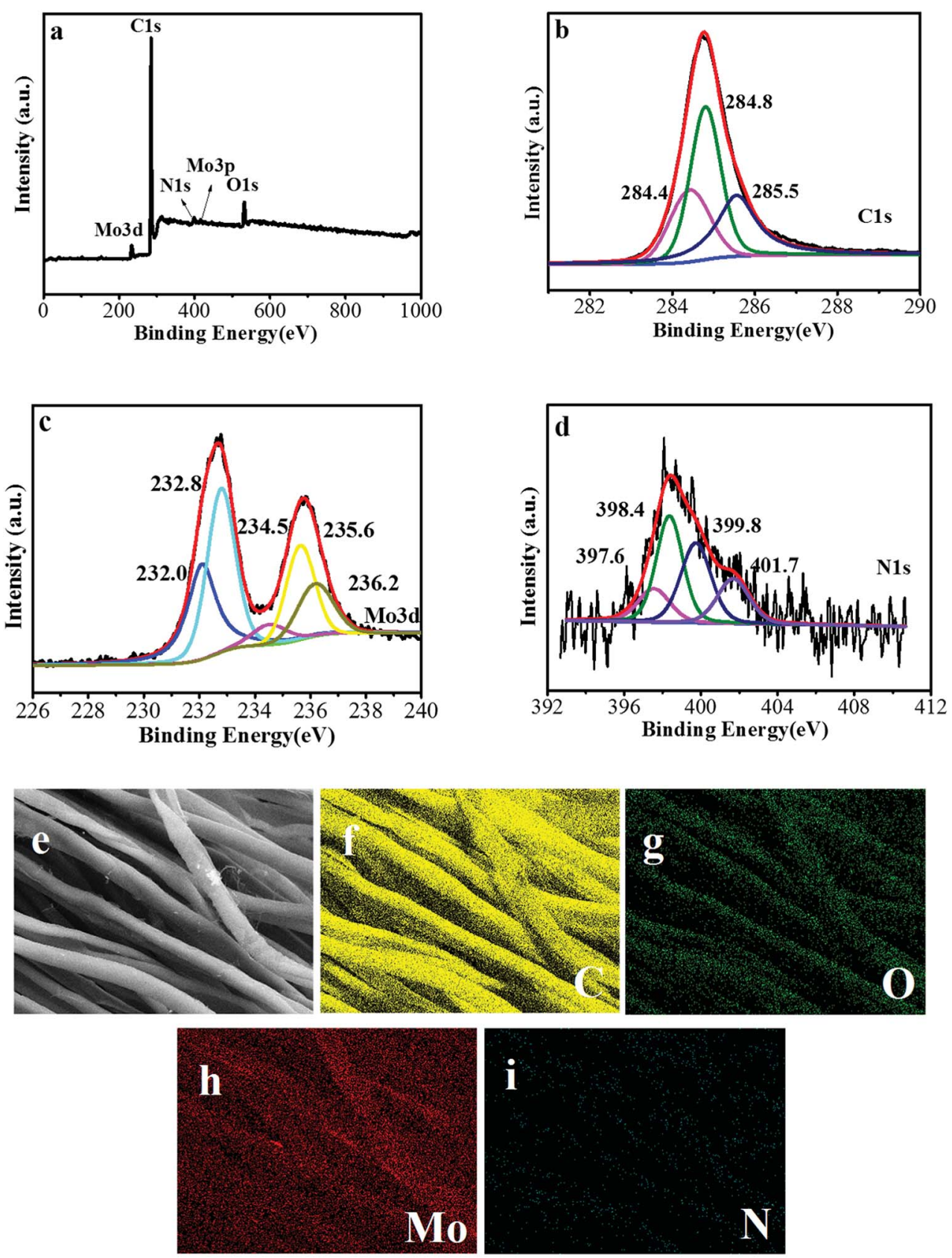

Fig. 4 X-ray photoelectron spectroscopy (XPS) survey of $\mathrm{Mo}_{2} \mathrm{C} / \mathrm{CCT}(\mathrm{a})$; high-resolution $\mathrm{C}$ 1s (b), Mo $3 \mathrm{~d}$ (c) and N 1s (d) XPS scans of Mo $2 \mathrm{C} / \mathrm{CCT}$ sample; and the SEM image of $\mathrm{Mo}_{2} \mathrm{C} / \mathrm{CCT}(\mathrm{e})$ and the corresponding quantitative EDS element mapping of $\mathrm{C}(\mathrm{f}), \mathrm{O}(\mathrm{g}), \mathrm{Mo}(\mathrm{h})$, and $\mathrm{N}$ (i).

$\mathrm{Mo}_{2} \mathrm{C} / \mathrm{CCT}$ and quantitative element mapping of $\mathrm{C}, \mathrm{O}$, Mo, and $\mathrm{N}$ are presented in Fig. 4e-i. As obviously seen from Fig. 4e$\mathrm{i}$, the $\mathrm{C}, \mathrm{O}$, Mo and $\mathrm{N}$ elements are evenly distributed on the surface of textile fibers, the content of $\mathrm{N}$ is the smallest, which is consistent with the XPS results.

\subsection{Performance of MFCs}

Compared with the blank CCT and unmodified carbon felt electrodes, the $\mathrm{Mo}_{2} \mathrm{C} / \mathrm{CCT}$ electrode was used as the anode for MFC. The batch-fed MFC was inoculated with mixed bacterial suspension from the effluent of matured single-chamber MFC, and then operated using sodium acetate as sole anodic electron donor $\left(1 \mathrm{~g} \mathrm{~L}^{-1}\right)$. As depicted in Fig. 5a, when the voltage output drops around $0 \mathrm{~V}, 80 \%$ of anolyte of each MFC is replaced with the fresh anolyte. Subsequently, the current density quickly increases to the highest value, and then gradually declines due to the depletion of anolyte. After five cycles of operation, the relatively stable cell voltages for MFCs equipped with $\mathrm{Mo}_{2} \mathrm{C} / \mathrm{CCT}$ and CCT anodes are obtained. However, the MFC equipped with unmodified carbon felt (Fig. S1a $\dagger$ ) anode just started up successfully after $200 \mathrm{~h}$. It is also observed that the $\mathrm{Mo}_{2} \mathrm{C} / \mathrm{CCT}$ anode delivers the larger cell voltage than the CCT and the unmodified carbon felt (Fig. S1a $\dagger$ ) anodes. 



Fig. 5 Voltage output versus time during start-up of the MFCs with different anodes with $1000 \Omega$ resistance loading (a); polarization curves and power outputs of different anodes in the MFCs (b).

The power production and polarization behavior of MFC were investigated after stable operation for three weeks of MFCs (Fig. 5b). It can be implied from Fig. 5a that the anode material has little influence on the open circuit voltage, but has an important effect on the power density. As illustrated in Fig. $5 \mathrm{~b}$ and $\mathrm{S} 1 \mathrm{~b}, \dagger$ the MFC equipped with $\mathrm{Mo}_{2} \mathrm{C} / \mathrm{CCT}$ anode delivers the maximum power density $\left(1.12 \mathrm{~W} \mathrm{~m}^{-2}\right)$, which is $51 \%$ and $116 \%$ higher than that of CCT and unmodified carbon felt anodes, respectively. Table S1 $\uparrow$ shows a comparison of the performance of MFCs with different anode materials under the same type of single-chamber MFC and inoculum. It could be concluded that the anode performance can be greatly improved due to the modification of $\mathrm{Mo}_{2} \mathrm{C}$ nanoparticles on the surface of CCT.

What's more, the power density of MFCs is related with the amount of $\mathrm{Mo}_{2} \mathrm{C}$ nanoparticles on the surface of carbonized cotton textile, which can be seen from Fig. S3. $\dagger$ The power densities of MFCs equipped with $\mathrm{Mo}_{2} \mathrm{C} / \mathrm{CCT}-1$ and $\mathrm{Mo}_{2} \mathrm{C} / \mathrm{CCT}-$ 3 anode are $0.80 \mathrm{~W} \mathrm{~m}^{-2}$ and $0.92 \mathrm{~W} \mathrm{~m}^{-2}$, respectively, which are less than that of $\mathrm{Mo}_{2} \mathrm{C} / \mathrm{CCT}$. The different concentration of precursor solution leads to the inconsistency of the growth of $\mathrm{Mo}_{2} \mathrm{C}$ nanoparticles on the CCT surface. Because of the low concentration of precursor solution, the amount of $\mathrm{Mo}_{2} \mathrm{C}$ nanoparticles on the surface of the carbonized cotton textile is small and the distribution of $\mathrm{Mo}_{2} \mathrm{C}$ nanoparticles may be not uniform. While, an excess of concentration of precursor solution, the $\mathrm{Mo}_{2} \mathrm{C}$ nanoparticles coating may fall off. Therefore, the concentration of the precursor solution of $2 \mathrm{~mol} \mathrm{~L}^{-1}$ is more suitable.

\subsection{Electrochemical activity}

To confirm the anodic performance, the potential responses were measured from $\mathrm{Mo}_{2} \mathrm{C} / \mathrm{CCT}$ and CCT anodes in half-batch experiments with an applied current of $0.1 \mu \mathrm{A}$, reflecting the polarization of the anodes. As described in our previous reports, the more negative the electrode potential, the better the anode activity. ${ }^{7,8}$ As presented in Fig. 6a, the electrode potential of $\mathrm{Mo}_{2} \mathrm{C} / \mathrm{CCT}$ is more negative than that of CCT, indicating that the $\mathrm{Mo}_{2} \mathrm{C} / \mathrm{CCT}$ electrode possesses superior electrochemical activity, owing to the $\mathrm{Mo}_{2} \mathrm{C}$ nanoparticles coating. Besides, it can be found that the $\mathrm{Mo}_{2} \mathrm{C} / \mathrm{CCT}$ electrode is very stable after constant-current discharge experiment for $20 \mathrm{~h}$.

EIS measurement was carried out on the MFCs after inoculation to investigate the effect of $\mathrm{Mo}_{2} \mathrm{C} / \mathrm{CCT}$ on the electron transfer efficiency from bacteria to the anode. Fig. $6 \mathrm{~b}$ presents the electrochemical impedance spectra of the $\mathrm{Mo}_{2} \mathrm{C} / \mathrm{CCT}$ and CCT electrodes. The $R_{\mathrm{ohm}}$ is ascribed to the ionic conductivity of the solution and the electronic conductivity of the electrode materials. ${ }^{34,35}$ As Fig. 6b shown, $R_{\mathrm{ohm}}$ of $\mathrm{Mo}_{2} \mathrm{C} / \mathrm{CCT}$ is smaller than that of CCT electrode, owing to the high conductivity of $\mathrm{Mo}_{2} \mathrm{C}$ nanoparticles. What is more, the electrical resistivity of $\mathrm{Mo}_{2} \mathrm{C} / \mathrm{CCT}\left(2.69 \Omega \mathrm{sq}^{-1}\right)$ is smaller than that of CCT (7.56 $\Omega$ $\mathrm{sq}^{-1}$ ), which was recorded on a four-probe conductivity measurement device. Thus, the $\mathrm{Mo}_{2} \mathrm{C} / \mathrm{CCT}$ electrode has higher conductivity than CCT electrode. $R_{\mathrm{ct}}$ is the charge transfer resistance, which suggests the mechanism of electron transfer between the bacteria and the anode. ${ }^{34}$ It is worth noting that the $R_{\text {ct }}$ of $\mathrm{Mo}_{2} \mathrm{C} / \mathrm{CCT}$ electrode $(11 \Omega)$ is smaller than that of CCT electrode $(57 \Omega)$. The result suggests that the $\mathrm{Mo}_{2} \mathrm{C}$ significantly reduces the electron transfer resistance but enhances the charge transfer rate between bacteria and anode. ${ }^{36}$

\subsection{Biofilm of $\mathrm{Mo}_{2} \mathrm{C} / \mathrm{CCT}$}

The biocompatibility of the anode is mainly reflected in the easiness of biofilm formation on its surface. ${ }^{22}$ The morphology of the biofilms on the $\mathrm{Mo}_{2} \mathrm{C} / \mathrm{CCT}$ and CCT electrodes were characterized by SEM after two months of steady operation. As displayed in Fig. 7a and b, the entire surface of the electrode is covered with rod-shaped bacterial cells. With the good biocompatibility of $\mathrm{Mo}_{2} \mathrm{C} / \mathrm{CCT}$, the electrode fiber is wrapped by bacterial cells (Fig. 7c). It can be seen from the high-resolution SEM image (Fig. 7d) that bacterial cells are connected with each other by microbial nanowires (shown by the arrows) and the $\mathrm{Mo}_{2} \mathrm{C} / \mathrm{CCT}$ electrode isn't blocked by the bacterial cells after two months of operation. As a result, stable operation of the MFCs using $\mathrm{Mo}_{2} \mathrm{C} / \mathrm{CCT}$ anode is realized. However, a small amount of bacteria adhered on the CCT electrode can be found (Fig. 7e and f) and just a few bacterial cells are observed on the carbon felt electrode (Fig. S3†), which indicated that the modification of 

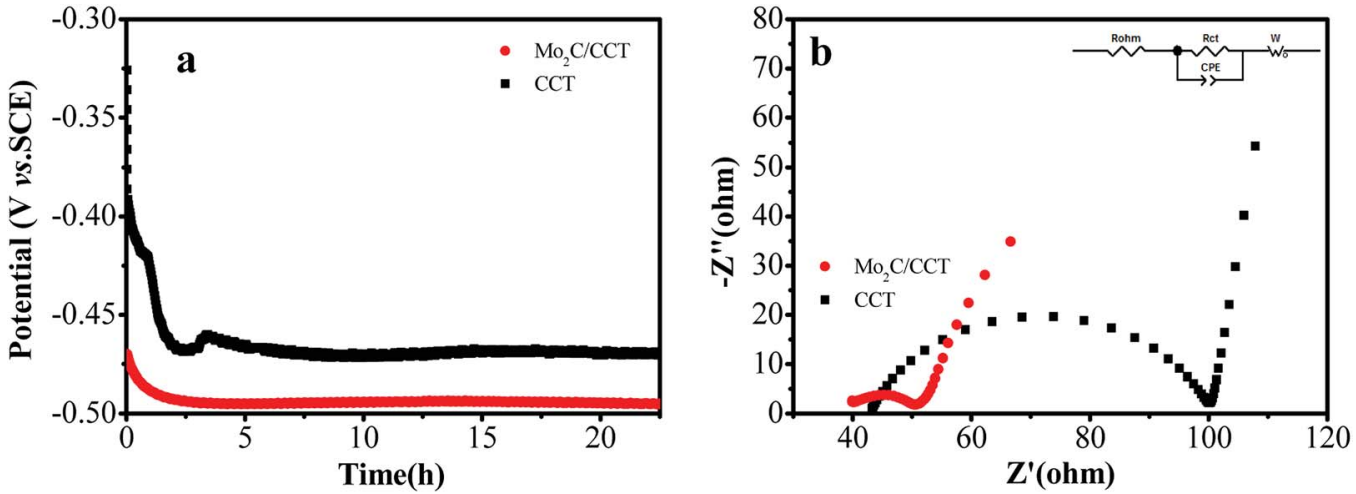

Fig. 6 Potential-time curves of different electrodes under a constant current of $0.1 \mu \mathrm{A}(\mathrm{a})$; electrochemical impedance spectra of the electrodes (b) (inset: the equivalent circuit).

$\mathrm{Mo}_{2} \mathrm{C}$ nanoparticles on the surface of CCT is beneficial to enhance the bacterial adhesion, further facilitates the formation of electroactive biofilm on the electrode.

With the above results, the electron-transfer mechanism at $\mathrm{Mo}_{2} \mathrm{C} / \mathrm{CCT}$ electrode was concluded as shown in Fig. S4. $\dagger$ The electrons from the microbial metabolism are directly transferred to the $\mathrm{Mo}_{2} \mathrm{C} / \mathrm{CCT}$ electrode via direct contact or nanowires. Due to good biocompatibility of $\mathrm{Mo}_{2} \mathrm{C}$ nanoparticles, bacterial cells are firmly attached to the surface of fiber through the electrostatic interaction between bacteria with rough
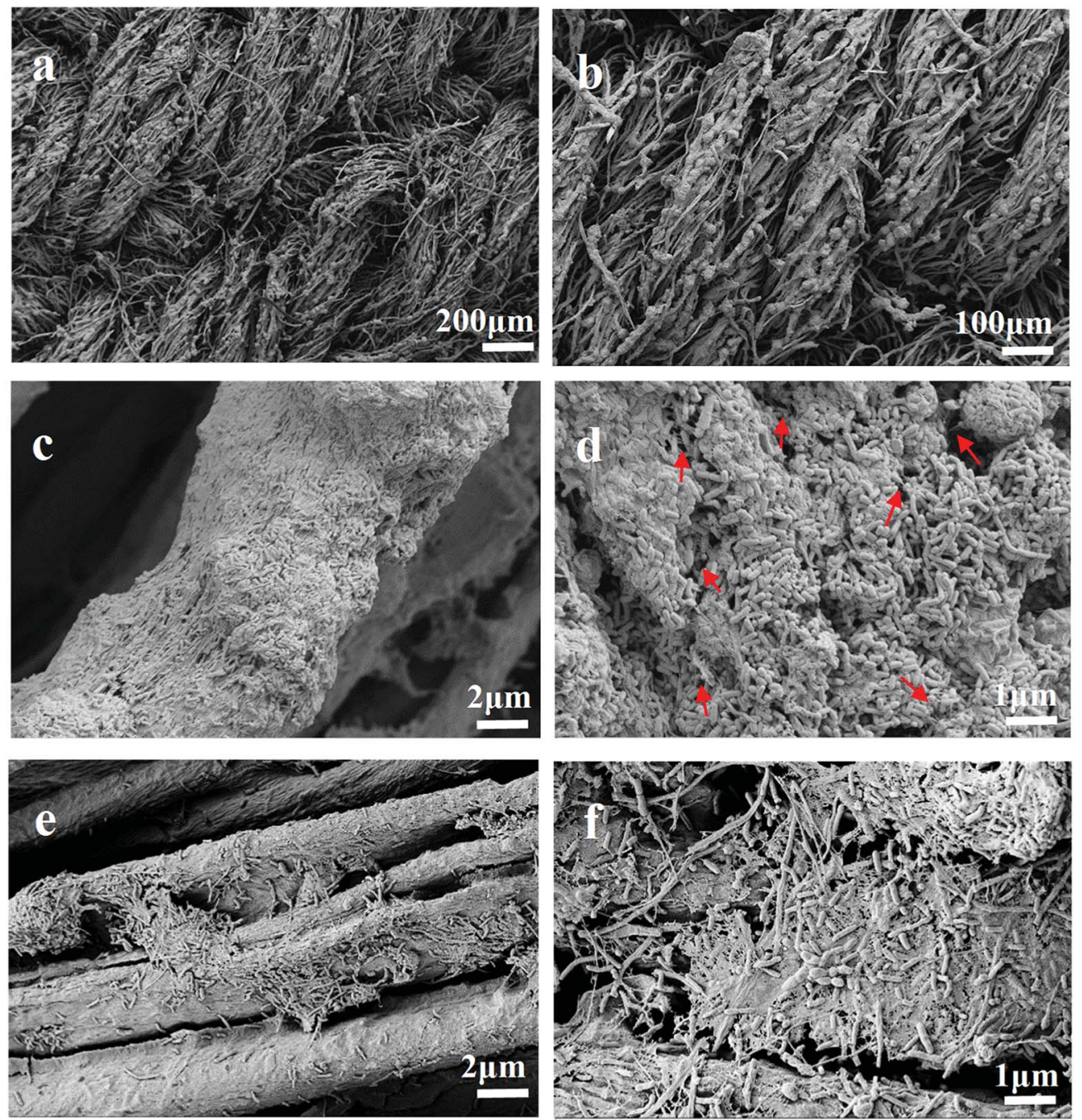

Fig. 7 SEM images of the electroactive biofilm grown on the $\mathrm{Mo}_{2} \mathrm{C} / \mathrm{CCT}(\mathrm{a}-\mathrm{d})$ and CCT (e and $\mathrm{f}$ ) anodes after two months of operation at various magnifications. 
surface of $\mathrm{Mo}_{2} \mathrm{C}$ nanoparticles (Fig. S4 $\dagger$ ), which facilitates the formation of electroactive biofilm. Moreover, $\mathrm{Mo}_{2} \mathrm{C}$ nanoparticles possess the superior conductivity and electrochemical activity, which can accelerate the metabolically generated electrons transfer to the textile fiber (electrode).

\section{Conclusions}

In summary, we have successfully prepared the $\mathrm{Mo}_{2} \mathrm{C} / \mathrm{CCT}$ as an anode material for high-performance MFCs via a facile two-step method (dipping and carbonization treatment). The results show that the $\mathrm{Mo}_{2} \mathrm{C} / \mathrm{CCT}$ electrode offers a rough surface and a great specific surface area for bacterial adhesion on the anode, hence facilitates the formation of electroactive biofilm, as well as displays superior electrochemical activity and enhances the charge transfer rate between bacteria and electrode. The MFC using $\mathrm{Mo}_{2} \mathrm{C} / \mathrm{CCT}$ anode has better performance than which using CCT and unmodified carbon felt anodes. This paper demonstrates a feasible way to prepare cost-effective and highperformance anode material for MFCs.

\section{Conflicts of interest}

There is no conflict of interest to declare.

\section{Acknowledgements}

The authors are highly grateful for Guangzhou Science \& Technology Project of Guangdong Province, China (201604016095 and 2016201604030035), Zhongshan Science and Technology Planning Project of Guangdong Province, China (2017A1008), Science and Technology Planning Project of Guangdong Province (2015B010112002), and CAS Key Laboratory of Environmental and Applied Microbiology \& Environmental Microbiology Key Laboratory of Sichuan Province, Chengdu Institute of Biology, CAS (No. KLCAS-2018-2).

\section{References}

1 Y. Zhao, Y. Ma, T. Li, Z. Dong and Y. Wang, RSC Adv., 2018, 8, 2059-2064.

2 S. Chang, B. Huang, T. Wan, J. Chen and B. Chen, RSC Adv., 2017, 7, 56433-56439.

3 S. Kalathil and D. Pant, RSC Adv., 2016, 6, 30582-90592.

4 S. Chen, J. Tang, X. Jing, Y. Liu, Y. Yuan and S. Zhou, Electrochim. Acta, 2016, 212, 883-889.

5 L. Yang, W. Deng, Y. Zhang, Y. Tan, M. Ma and Q. Xie, Biosens. Bioelectron., 2017, 91, 644-649.

6 Y. Yuan, T. Liu, P. Fu, J. Tang and S. Zhou, J. Mater. Chem. A, 2015, 3, 8475-8482.

7 L. Zeng, W. Zhang, P. Xia, W. Tu, C. Ye and M. He, Biosens. Bioelectron., 2018, 102, 351-356.

8 L. Zeng, S. Zhao and M. He, J. Power Sources, 2018, 376, 3340.

9 B. E. Logan, Appl. Microbiol. Biotechnol., 2010, 85, 1665-1671. 10 Y. Fan, E. Sharbrough and H. Liu, Environ. Sci. Technol., 2008, 42, 8101-8107.
11 Y. C. Yong, X. C. Dong, M. B. Chan-Park, H. Song and P. Chen, ACS Nano, 2012, 6, 2394-2400.

12 D. Chen, X. Zhuang, J. Zhai, Y. Zheng, H. Lu and L. Chen, Sens. Actuators, B, 2018, 255, 1500-1506.

$13 \mathrm{X}$. Zhuang, C. Tian, F. Luan, X. Wu and L. Chen, RSC Adv., 2016, 6, 92541-92546.

14 H. B. Wu, B. Y. Xia, L. Yu, X. Y. Yu and X. W. Lou, Nat. Commun., 2015, 6, 6512.

15 Y. Zhao, K. Kamiya, K. Hashimoto and S. Nakanishi, J. Am. Chem. Soc., 2015, 137, 110-113.

16 F. X. Ma, H. B. Wu, B. Y. Xia, C. Y. Xu and X. W. Lou, Angew. Chem., Int. Ed., 2015, 54, 15395-15399.

17 L. Liao, S. Wang, J. Xiao, X. Bian, Y. Zhang, M. D. Scanlon, X. Hu, Y. Tang, B. Liu and H. H. Girault, Energy Environ. Sci., 2014, 7, 387-392.

18 Q. Bkour, C. M. Cuba-Torres, O. G. Marin-Flores, S. Tripathi, N. Ravishankar, M. G. Norton and S. Ha, J. Mater. Sci., 2018, 53, 12816-12827.

19 W. Dai, H. Dong and X. Zhang, Materials, 2018, 11, 17761786.

20 L. Zeng, L. Zhang, W. Li, S. Zhao, J. Lei and Z. Zhou, Biosens. Bioelectron., 2010, 25, 2696-2700.

21 L. Zeng, S. Zhao and W. Li, Appl. Biochem. Biotechnol., 2015, 175, 2637-2646.

22 Y. Wang, B. Li, D. Cui, X. Xiang and W. Li, Biosens. Bioelectron., 2014, 51, 349-355.

23 B. Logan, S. Cheng, V. Watson and G. Estadt, Environ. Sci. Technol., 2007, 41, 3341-3346.

24 Y. Yuan, S. G. Zhou, Y. Liu and J. H. Tang, Environ. Sci. Technol., 2013, 47, 14525-14532.

25 T. C. Xiao, A. P. E. York, H. Al-Megren, C. V. Williams, H. T. Wang and M. L. H. Green, J. Catal., 2001, 202, 100-109.

26 L. Pan, Y. Li, S. Yang, P. Liu, M. Yu and H. Yang, Chem. Commun., 2014, 50, 13135-13137.

27 J. Qiu, Z. Yang, Q. Li, Y. Li, X. Wu, C. Qi and Q. Qiao, J. Mater. Chem. A, 2016, 4, 13296-13306.

28 L. Zhou, L. Sun, P. Fu, C. Yang and Y. Yuan, J. Mater. Chem. A, 2017, 5, 14741-14747.

29 H. Li, H. Ye, Z. Xu, C. Wang, J. Yin and H. Zhu, Phys. Chem. Chem. Phys., 2017, 19, 2908-2914.

30 Y. Zhu, S. Wang, Y. Zhong, R. Cai, L. Li and Z. Shao, J. Power Sources, 2016, 307, 552-560.

31 Q. Gao, X. Zhao, Y. Xiao, D. Zhao and M. Cao, Nanoscale, 2014, 6, 6151-6157.

32 J. Tang, S. Chen, Y. Yuan, X. Cai and S. Zhou, Biosens. Bioelectron., 2015, 71, 387-395.

33 Y. J. Feng, Q. Yang, X. Wang and B. E. Logan, J. Power Sources, 2010, 195, 1841-1844.

34 H. Li, B. Liao, J. Xiong, X. Zhou, H. Zhi, X. Liu, X. Li and W. Li, J. Power Sources, 2018, 379, 115-122.

35 L. Zeng, X. Chen, H. Li, J. Xiong, M. Hu, X. Li and W. Li, Electrochim. Acta, 2018, 283, 528-537.

36 C. Zhang, P. Liang, X. Yang, Y. Jiang, Y. Bian, C. Chen, X. Zhang and X. Huang, Biosens. Bioelectron., 2016, 81, 3238. 